\title{
CONDIÇÕES DE PRODUÇÃO EM COMANDOS DE ESCRITA DO EXAME CELPE-BRAS
}

\section{CONDITIONS OF PRODUCTION IN CELPE-BRAS EXAMINATION WRITING COMMANDS}

\author{
Adriana Dalla Vecchia49 \\ Renilson José Menegassi5051**
}

\begin{abstract}
RESUMO: Este artigo tematiza as condiçôes de produçáo em comandos de produçáo escrita do exame ofertado pelo Certificado de Proficiência em Língua Portuguesa para Estrangeiros/CELPE-BRAS, objetivando mostrar se houve mudanças relativas à conduçâo dos testes de produçáo escrita desse exame, desde sua primeira até a última prova. Avaliamos se os comandos oferecem condiçóes para o candidato fazer uma produçấo textual com ancoragem em situaçôes sociais de interaçăo e problematizamos a noçăo de proficiência escrita implícita na construçăo do exame. A discussăo filia-se à Linguística Aplicada, tomando como base a concepçâo dialógica da linguagem e ênfase na abordagem sócio-histórica, sendo uma análise documental, em que sāo consideradas as ediçōes exames do CELPE-BRAS de 1998/1, 2006/1 e 2014/1.
\end{abstract}

Palavras-chave: Escrita; Condiçōes de Produçăo; Proficiência; CELPE-BRAS.

ABSTRACT: This article thematizes production conditions in writing production examination commands offered by the Certificado de Proficiência em Língua Portuguesa para Estrangeiros/CELPE-BRAS, aiming to show whether there were changes on the written production tests conduct, since its first until itw last race. We evaluate whether the analyzed commands provided conditions for the candidate produces a textual production anchored in social interaction situations and we discuss the notion of implicit writing proficiency exam construction. The discussion is located in the field of Applied Linguistics, based on dialogical conception of language and emphasis socio-historical approach. From this theoretical scope, CELPE-BRAS examinations are analyzed, in its editions of 1998/1, 2006/1 and 2014/1.

Keywords: Writing; Production Conditions; Proficiency; CELPE-Bras.

49 Doutoranda do Programa de Pós-Graduaçâo em Letras da Universidade Estadual de Maringá (UEM). adrianarevisao@gmail.com

50 Docente do Programa de Pós-Graduaçăo em Letras da Universidade Estadual de Maringá (UEM). renilson@wnet.com.br 


\section{CONSIDERAÇÕES INICIAIS}

Aprender uma língua estrangeira ou, como entendemos, língua adicional, é uma prática comum, mas, em situaçóes como a realizaçăo de intercâmbio entre países ou o ingresso em programas de pós-graduaçấo, nâo basta saber falar e/ou escrever, é preciso comprovar essas habilidades. Considerando tais necessidades, alguns exames que avaliam a proficiência dos indivíduos foram sendo criados para suprir a demanda emergente. Exemplos conhecidos de exames como esses săo o TOEFL (Test of English as a Foreign Language), criado em 1964, o DELE (Diploma de Espanhol como Língua Estrangeira), criado e reconhecido pelo Ministério da Educaçăo, Cultura e Esporte da Espanha, em 1988, o DELF - Diplôme d"Etudes en Langue Française e o DALF Diplôme Approfondi de Langue Française, exames criados em 22 de maio de 1985, pela Commission Nationale du Delf et du Dalf.

Ao submeterem-se a tais avaliaçôes, os candidatos podem atestar seu nível de proficiência nas línguas-alvo, o português, entretanto, por muito tempo, năo teve um exame que certificasse os aprendizes da língua. A fim de suprir essa falta, foi criado o Certificado de Proficiência em Língua Portuguesa para Estrangeiros (CELPE-BRAS), atribuído aos estrangeiros com desempenho satisfatório em exame padronizado de português, desenvolvido pelo Ministério da Educaçăo, organizado, desde o segundo semestre de 2009, mais especificamente, pelo Instituto Nacional de Estudos e Pesquisas Educacionais Anísio Teixeira (INEP).

Trata-se de uma certificaçâo oficial e internacionalmente reconhecida e aceita em empresas e instituiçôes de ensino como comprobatória de competência em língua portuguesa, sendo exigida para ingresso em cursos de graduaçấo e em programas de pós-graduaçáo. O CELPE-BRAS é aplicado em vários postos no Brasil e em outros países com o apoio do Ministério das Relaçóes Exteriores. Sua avaliaçâo abrange quatro níveis: intermediário, intermediário superior, avançado e avançado superior. O primeiro teste foi aplicado em 1998.

Neste texto, fazemos uma análise documental, em que avaliamos os comandos de produçáo escrita do exame CELPE-BRAS, nas suas ediçōes de 1998/1, 2006/1 e 2014/1, procurando mostrar se houve ou năo mudanças relativas à conduçáo dos testes de produçâo escrita. Consideramos se o comando oferece condiçóes para que o candidato faça uma produçăo textual com ancoragem em situaçôes sociais de interaçâo. Por meio dessa discussăo, tecemos consideraçōes sobre a noçăo de proficiência escrita implícita na construçăo do exame, a qual pode sinalizar para uma prática docente em português como língua adicional.

Este trabalho situa-se no campo da Linguística Aplicada, tomando como base a concepçâo dialógica da linguagem e ênfase na abordagem sócio-histórica. Para fazer a discussâo proposta, inicialmente, definimos e caracterizamos os conceitos propostos nos textos do Círculo de Bakhtin relativo às práticas de escrita. Tais conceitos se agrupam para formar o que Geraldi (2003) chama de condiçóes de produçăo, pois sâo elementos norteadores da produçâo textual, sendo assim subsídios e parâmetros para o trabalho de escrita. Em seguida, apresentamos as concepçōes de proficiência em língua adicional que foram se estabelecendo ao longo dos estudos linguísticos de modo a entender qual delas está subjacente à construçâo do exame CELPE-BRAS. Finalizamos o artigo com a análise dos comandos de produçấo escrita do exame aplicado em 1998/1, em 
2006/1 e em 2014/1, considerando os elementos componentes das condiçôes de produçăo de um texto escrito em si e para a construçáo da noçáo de proficiência escrita.

\section{CONDIÇÕES DE PRODUÇÃO E OS ELEMENTOS CONSTITUINTES}

Os conceitos que compôem o que Geraldi (2003) chama de condiçôes de produçâo estăo embasados nas discussôes e orientaçôes dos estudiosos do Círculo de Bakhtin. Tais pensadores se ocuparam da linguagem, buscando entendê-la a partir do seu uso, ou seja, sempre abordaram a linguagem tendo como princípio sua posiçâo sócio-histórico-ideológico-valorativa. Isso se identifica com a prática diária, cuja característica principal está no fato de haver uma situaçăo real de interaçăo e uma forma de linguagem ser acionada para mediar as açôes. Essa prática de linguagem, desse modo, é situada em contexto social, determinado historicamente, perpassada por ideologias e valores da comunidade da qual fazem parte os interlocutores em interaçăo.

Essa concepçăo de linguagem como forma de interaçăo permite a compreensâo de que toda prática de linguagem só é possível porque existem condiçôes para que o discurso seja construído, tanto oralmente, como na forma escrita. Em geral, essa visăo se choca com as práticas tradicionais de trabalho com o texto na escola, cuja orientaçăo leva o professor a propor, por exemplo, escrita de um texto sem que as condiçóes de produçăo sejam satisfeitas, o que gera uma atividade de escrita artificial. Outro exemplo refere-se à redaçăo (texto dissertativo-argumentativo), que normalmente nâo tem finalidade nem funçăo social, solicitada em vestibulares de algumas instituiçôes. ${ }^{52}$

As condiçôes de produçâo de um texto escrito, sistematizadas por Geraldi (2003), delineiam os seguintes elementos para que a produçâo seja mais significativa:

se tenha o que dizer;

se tenha uma razâo para dizer o que se tem a dizer;

se tenha para quem dizer o que ser tem a dizer;

o locutor se constitua como tal, enquanto sujeito que diz o que diz para quem diz [...]; se escolham as estratégias para realizar (a), (b), (c) e (d). (GERALDI, 2003, p. 137)

Essa sistematizaçăo guia muitos trabalhos em produçăo textual em língua materna, sendo, como afirma Menegassi (2012), um direcionamento de trabalho para os professores na conduçâo dessa prática discursiva em sala de aula. Observamos que náo somente em língua materna, mas também em língua adicional tais elementos tornamse importantes para e enunciaçâo no sentido de que marcam o enunciado pela temporalidade e respectivas dimensōes, situando, portanto, o texto a ser escrito, retirando-o de um ato monológico.

Os elementos citados se embasam em conceitos bakhtinianos, como: finalidade, interlocutor, gênero discursivo (temática, estrutura composicional e estilo), circulaçâo

52 Faz-se aqui uma ressalva, pois reconhecemos que essas práticas tradicionais, embora estejam enraizadas na escola, náo ocupam única e exclusivamente as aulas de português, há, por exemplo, presença significativa da abordagem de gêneros textuais que nâo se preocupa apenas com os aspectos formais/ estruturais dos textos, mas sim o abordam de modo mais significativo, considerando seu contexto de produçăo, os interlocutores potenciais e outras condiçôes de produçăo. 
social, suporte textual e posiçâo do autor. Tais conceitos săo abordados em pelo menos três obras do Círculo de Bakhtin: Discurso na vida e discurso na arte (1972); Marxismo e filosofia da linguagem (2009); e Estética da criaçăo verbal (2003). Para entender as condiçôes de produçâo para, entăo, analisar os comandos do exame do CELPE-BRAS, explanamos sobre eles brevemente, associando com a citaçăo acima de Geraldi.

O primeiro dos conceitos, o de finalidade ou intençâo discursiva (BAKHTIN, 2003), refere-se ao objetivo da escrita. Todo enunciado real só é constituído a partir de uma razăo, o enunciado, em seu volume e fronteiras, é determinado por esse querer dizer do falante. Esse conceito refere-se ao que Geraldi relaciona como "se tenha uma razăo para dizer o que se tem a dizer" (2003, p. 137), aquele que escreve a partir de uma finalidade real se torna autor de seus textos, sabendo por que escreve. Observa-se, assim, a importância desse item para a escrita, pois indica a conclusibilidade do enunciado, permitindo a possibilidade de o interlocutor responder. Desse modo, se o comando para uma produçâo escrita em situaçăo de exame CELPE-BRAS apresenta a finalidade da açáo do candidato, esta será mais bem orientada e sua produçăo fará mais sentido para ele próprio já que será motivada.

A intençâo de dizer geralmente traz à tona outro elemento, o interlocutor, pois, em situaçōes de interaçôes sociais, é consenso que o locutor se dirige a alguém, retomando Geraldi (2003), há um querer-dizer algo a alguém. Nos textos do Círculo de Bakhtin, está o interlocutor pressuposto no termo interaçấo e enunciado como ouvinte, interlocutor, auditório, outro e destinatário. A partir desses termos, já se conjetura que o discurso parte de alguém em direçăo a um outro, como Volochínov/Bakhtin (2009, p. 117) dizem "toda palavra comporta duas faces", pois da mesma forma que "procede de alguém [...] se dirige para alguém". Esse participante da interaçăo é denominado em cada texto do Círculo de modo diferente, entretanto, com uma leitura atenta, entendese que se trata do mesmo aspecto com nuances novos. A funçâo do interlocutor é de extrema importância, pois o falante tendo a imagem do outro ao produzir o discurso, selecionará o gênero discursivo que melhor atenderá o objetivo de interaçâo para alcançar seu outro. Assim, esse elemento é um "traço essencial (constitutivo) do enunciado" (BAKHTIN, 2003, p. 301).

O termo interlocutor sugere a recepçâo do discurso do locutor, bem como a própria resposta a este. $\mathrm{O}$ outro, por sua vez, permite que se entenda a interaçấo verbal como um processo interpessoal e também intrapessoal, ou seja, há outro de si com quem o locutor dialoga para formular seu discurso antes de externalizá-lo para o outro externo. O outro externo, por sua especificidade, refere-se, segundo os estudiosos do Círculo de Bakhtin, a três tipos de interlocutores: o real, o qual tem uma imagem física presente durante a interaçấo; o ideal/virtual, cuja imagem é construída pelo locutor, pois nâo está presente durante a situaçáo de interaçăo, sendo ele quem determina as regras de produçăo oral ou escrita; por fim, há o interlocutor supraindividual/superior, um representante oficial que constitui regras as quais săo respeitadas no ambiente social onde ocorre a interaçáo (VOLOCHINOV/BAKHTIN, 2009).

Relacionando esses tipos de interlocutores com a situaçăo de exame do CELPEBRAS, podemos afirmar que o interlocutor real do candidato é a banca examinadora da prova, pois é a ela a quem se dirige. Embora ele tenha um interlocutor marcado no comando a quem se dirige virtualmente, há alguém que receberá a prova para avaliar, 
o interlocutor real. Aquele a quem o candidato se direciona virtualmente é o interlocutor ideal/virtual, pois está ausente durante a situaçâo de interaçăo, mas é a ele que o discurso deverá ser moldado. No exemplo, temos ainda o interlocutor superior, que estabelece as normas e padróes de interaçấo a serem seguidos pelos envolvidos naquele meio social, o INEP (Instituto Nacional de Estudos e Pesquisas Educacionais Anísio Teixeira), o qual regulamenta como devem ser respondidas as questôes e quais competências e habilidades sâo exigidas dos candidatos.

Conforme Bakhtin (2003, p. 282, grifo do autor) explica, a intençâo discursiva do locutor se dá também "na escolha de um certo gênero de discurso." Tal opçăo é feita em funçăo do campo da comunicaçăo discursiva que envolve, dentre outras características, a situaçáo concreta de interaçấo e a composiçâo pessoal dos participantes. Nesse sentido, tem-se que a partir do gênero a intençấo discursiva se tornará escrita, como observam Fuza e Menegassi (2008). Os gêneros, em sendo "tipos relativamente estáveis de enunciados" (BAKHTIN 2003, p. 262, grifo do autor), possuem determinados elementos que o compóem: conteúdo temático, que se refere às temáticas possíveis para determinado gênero, nâo sendo o assunto em si, "abrange as diferentes atribuiçôes de sentidos e seus recortes possíveis para um dado gênero do discurso" (MONTERANI; MENEGASSI, 2010, p. 226); estilo da linguagem relaciona-se à escolha de recursos linguísticos (fraseológicos, gramaticais e lexicais) pelo locutor no intuito de alcançar seu interlocutor para dele obter uma resposta; e construçâo composicional refere-se às características que fazem do gênero um tipo de enunciado relativamente estável, ou seja, a estruturaçáo textual, a qual dá ao texto possibilidade de ser reconhecido visualmente.

O estudo do gênero comporta o meio de circulaçăo social, isto é, o lugar social onde tal gênero alcançará o interlocutor pretendido. Quanto a esse elemento, cabe salientar dois desdobramentos a partir dos quais podemos compreendê-lo. Ao se abordar a noçáo de circulaçáo social pode-se estar se referindo ao suporte do texto, ao material físico que leva o texto (como o papel, o jornal, etc.) ou, entăo, a referência está na forma como o gênero chegará ao seu interlocutor (via rádio, internet, televisăo, mídia impressa, etc.) (MENEGASSI, 2012).

O suporte textual, como outro elemento do projeto de produçâo textual, é bastante importante, "é necessário, em funçăo do gênero escolhido, que se determine em qual portador o texto será produzido." (MENEGASSI, 2012, p. 258). Isso nos faz pensar que se o mesmo texto for publicado em um jornal da cidade ou em blog na internet, terá configuraçôes específicas determinadas pelo suporte que veiculará o texto. Do mesmo modo, uma resenha acadêmica, se publicada em periódico científico, terá características diferenciadas em termos de leiuaute, por exemplo, se for publicada em uma revista online de conteúdo científico.

No caso do exame do CELPE-BRAS, a circulaçăo social e o suporte ficam circunscritos à situaçăo da prova, pois, embora o comando ofereça ambas as informaçôes ao candidato, o texto a ser produzido por ele terá como suporte o papel e circulaçấo social restrita à banca examinadora. De todo modo, é de suma importância, como salientado acima, que se ofereçam tais informaçôes aos candidatos, já que assim ele estará mais amparado para sua produçăo textual.

Por fim, há ainda outro elemento que compôe as condiçôes de produçăo, a posiçáo-autor. Na produçâo textual, faz-se necessário que o locutor assuma uma posiçâo 
de sujeito autor, expressando sua individualidade. Segundo Bakhtin, "quanto melhor dominamos os gêneros tanto mais livremente os empregamos, tanto mais plena e nitidamente descobrimos nossa individualidade (onde é possível e necessária), refletimos de modo mais flexível e sutil a situaçăo singular da comunicaçăo" (2003, p. 285), realizando de forma mais acabada o próprio projeto de discurso. Entăo, em comandos de avaliaçăo de produçấo textual em geral, deve-se oferecer ao candidato a posiçấo-autor para que ele se posicione e expresse da maneira dele requerida sua subjetividade a respeito do tema, mostrando como percebe o tema.

As condiçôes de produçâo, ao serem oferecidas nos comandos de produçăo textual em exames de proficiência em língua adicional, ${ }^{53}$ permitem aos candidatos a reproduçâo de uma situaçăo real de interaçăo. Nesse sentido, é evidente a influência dos elementos que a compóem na escrita do candidato para avaliar se ele é proficiente no uso real da língua. Para discutir com mais propriedade sobre proficiência e, mais especificamente, proficiência escrita, no próximo item apresentamos alguns conceitos que nos auxiliarăo nas consideraçôes sobre a concepçăo de proficiência escrita do exame CELPE-BRAS a partir da análise dos comandos de escrita, considerando as condiçôes de produçấo.

\section{PROFICIÊNCIA EM LÍNGUA ADICIONAL: CONSIDERAÇÕES CONCEITUAIS}

Scaramucci, em uma visáo mais geral, diz que "ser proficiente em uma determinada língua poderia pressupor, portanto, conhecimento, domínio, controle, capacidade, habilidade, independentemente do significado que possamos dar a cada um desses termos". O conceito subjacente a essa perspectiva em relaçâo ao uso de línguas parece, segundo orienta a pesquisadora, "ter como referência o controle ou comando operacional do falante nativo ideal" (SCARAMUCCI 2000, p. 13), herança estruturalista. Assim considerada a proficiência, nota-se que ela năo depende em nada da situaçăo de interaçăo e dos elementos que compóem tanto uma produçâo oral quanto escrita. Basta, nessa perspectiva, conseguir usar a língua como o falante nativo o faz.

Nesse caso, o falante nativo é o parâmetro de avaliaçăo dos falantes náo nativos, mesmo que a proficiência daquele năo seja monolítica e unitária, uma vez que varia de acordo com o interlocutor, a situaçáo de uso, o barulho, o estresse dentre outros fatores. A proficiência monolítica revela também o conceito de língua que a conduz, como sendo um construto sistemático fechado e também monolítico, sem variaçăo e usado para um único fim, capaz de ser apreendido em todos os seus constituintes, distanciando-se da visăo de língua como forma de interaçăo, proposta por Geraldi (1997). Nesse uso do termo, considera-se o ser e o năo ser proficiente, gerando uma escala em que o nível zero, por exemplo, năo tem proficiência, mesmo que demonstre algum com conhecimento da língua adicional. Para ser considerado proficiente nessa língua, ampliando o exemplo, é preciso que se atinja o nível três, onde o indivíduo demonstra fluência (entendida, nessa visâo, como sinônima de proficiência) (SCARAMUCCI, 2000).

53 Utilizamos o termo língua adicional para fazer referência ao objeto de ensino da escola, língua estrangeira ou segunda língua (SCHLATTER;GARCEZ, 2009). Optou-se pelo termo, pois ele engendra o entendimento de que as línguas aprendidas na escola podem se somar ao repertório do aluno usado para sua atuaçāo em práticas sociais diversas na comunidade onde vive. 
Pensar proficiência por esse viés é assumir uma base estruturalista, cujos pressupostos também interferiram, segundo Scaramucci (2000), na elaboraçăo de testes de proficiência como o TOEFL (inglês). Para a autora, exames como esse săo organizados "em baterias de testes que, combinados, constituiriam uma forma considerada altamente válida de "medir" proficiência ou de se alcançar uma espécie de visăo global da capacidade do candidato" (SCARAMUCCI, 2000, p. 17). Nesses sistemas de controle, parece haver a compreensăo de que ser proficiente vincula-se ao controle operacional linguístico do falante nativo, ou seja, quanto mais o candidato se aproximar desse ideal de uso da língua, mais proficiente se mostrará. Essa hipótese gera a compreensâo de que ser proficiente é ter conhecimento sistemático sobre a língua adicional para poder analisá-la. Vem dessas consideraçôes a necessidade de se olhar para o exame do CELPE-BRAS e avaliar a sua concepçâo de proficiência, levando em conta como os comandos de produçăo sâo propostos.

O termo proficiência ainda tem um conceito relativo e múltiplo, pois considera "a especificidade da situaçăo de uso futuro da língua". Entra em jogo, aqui, a possibilidade de várias proficiências, ou seja, a situaçâo de uso exige níveis de proficiência diferentes. Isso quer dizer que as especificidades de uso da linguagem geram uma "gradaçăo de proficiência entre menos e mais proficientes" (UFLACKER, 2012). Nesse caso, Scaramucci valida falas como Ele é proficiente em Inglês para viver e estudar na Inglaterra ou Ele é proficiente em Inglês para trabalhar no Brasil como guia turístico (SCARAMUCCI, 2000, p. 14). Como se pode observar, nessa visâo é considerada a situaçăo de interaçăo e alguns dos elementos das condiçóes de produçăo já podem ser notados também, ou seja, no exemplo que trata de alguém ser proficiente para trabalhar como guia turístico no Brasil, temos a tomada de posiçăo do sujeito como guia turístico com um propósito específico, trabalhar no Brasil. Nesse caso, aprender inglês é para essa situaçấo social específica.

Nesse sentido, corroboramos a ideia de Fortes (2009) que entende proficiência como sendo um trabalho em conjunto levado a diante por todos os participantes de uma situaçấo de interaçấo para realizaçâo de suas atividades cotidianas, estando o ajuste ao interlocutor no centro do processo avaliativo. Wagner (1996 apud FORTES, 2009) afirma que o significado de proficiência se relaciona com uma realizaçâo conjunta, local e contingente, construída pelos participantes na interaçâo mediada pela linguagem. A explicaçâo do autor para essa afirmaçáo é no sentido de que, para ele, o uso da linguagem é um estabelecimento coordenado e conjunto feito pelos participantes devido ao ajuste ao interlocutor e aos demais elementos componentes da interação.

Nessa perspectiva, o compartilhamento de uma língua comum para interaçăo é imprescindível para que esta se efetive, mas isso náo garante necessariamente, como alerta Fortes, "a inexistência de problemas de entendimento na interpretaçăo pelos participantes das açôes uns dos outros mediante o uso da linguagem" (BAKHTIN/ VOLOCHINOV, 2009, p. 28). Segundo a autora, em funçáo dessa premissa, os participantes da interaçâo buscam recursos interacionais para resolver os problemas de compreensâo que possam comprometer a inteligibilidade comum durante o uso da língua de interaçăo que compartilham entre si. Isso quer dizer que estar numa mesma situaçăo contextual de uma língua adicional năo é garantia de que haja compreensăo, mesmo que os todos os participantes tenham conhecimento de tal língua, é preciso que eles utilizem recursos interacionais para se fazerem entender. 
Essa questăo relaciona-se ao que Bakhtin/Volochinov chamam de sinalidade da língua estrangeira, segundo o teórico, "no processo de assimilaçăo de uma língua estrangeira, sente-se a "sinalidade" e o reconhecimento, que năo foram ainda dominados: a língua ainda nâo se tornou língua". Ele ainda continua afirmando que "a assimilaçâo ideal de uma língua se dá quando o sinal é completamente absorvido pelo signo e o reconhecimento pela compreensáo" (BAKHTIN/VOLOCHINOV, 2009, p. 97-98). Desse modo, o fundamental na tarefa de compreensăo năo é exatamente reconhecer a forma utilizada, mas sim compreender sua significaçâo em uma enunciaçăo particular.

Essa ideia de proficiência sugere que toda produçâo em língua adicional seja em forma de enunciados concretos ${ }^{54}$, gerando uma consciência linguística tanto do falante quanto do interlocutor que vai além do conhecimento do sistema abstrato de formas normativas, considerando "a linguagem no sentido de conjunto de contextos possíveis de uso de cada forma particular" (BAKHTIN/VOLOCHINOV, 2009, p. 98).

Assumindo essa perspectiva de trabalho para o exame de proficiência em línguas adicionais, é preciso observar que "[o] centro organizador de toda enunciaçáo, de toda expressâo, nâo é interior, mas exterior: está situado no meio social que envolve o indivíduo" (BAKHTIN/VOLOCHINOV, 2009, p. 125). Desse modo, é de extrema relevância orientar os comandos de exames como o CELPE-BRAS, de modo que estes contemplem situaçóes reais, com interlocutores reais, de interaçâo. Isso vale tanto para a avaliaçâo da produçáo oral quanto da escrita do candidato, mas em especial quando se refere à proficiência escrita, satisfazer as condiçôes de produçăo já no comando, direciona melhor a açấo de linguagem do candidato, dando-lhe possibilidade de escrever um texto o mais autêntico possível dentro da situaçăo avaliativa.

\section{AS CONDIÇÕES DE PRODUÇÃO EM COMANDOS DE PRODUÇÃO ESCRITA DO EXAME CELPE-BRAS}

O exame CELPE-BRAS desde sua primeira aplicaçâo avalia a compreensăo oral, a compreensâo escrita, a produçâo oral e a produçâo escrita em língua portuguesa, de forma integrada, sendo composto de duas partes:

PARTEESCRITA (com duraçăo de três horas) - duas tarefas integrando compreensăo oral e produçăo escrita e duas tarefas integrando leitura e produçăo escrita;

PARTE ORAL (com duraçâo de vinte minutos) - interaçăo a partir de atividades e interesses mencionados pelo examinando na ficha de inscriçăo e conversa sobre tópicos do cotidiano, de interesse geral, com base em elementos provocadores. ${ }^{55}$

O candidato obtém seu certificado, quando alcança desempenho nas duas partes componentes do Exame. A partir desse desempenho, o examinando se encaixa em um dos quatro níveis de proficiência: Intermediário, Intermediário Superior, Avançado e Avançado Superior.

54 Segundo Bakhtin, enunciado concreto é uma unidade real da comunicaçâo discursiva, delimitada pela alternância de sujeitos, "a qual termina com a transmissăo da palavra ao outro" (BAKHTIN, 2003, p. 275).

Disponível em: <http://portal.inep.gov.br/celpebras-estrutura_exame> Acesso em: 17 out. 2014. 
Como o foco deste trabalho é a produçăo escrita, conferimos atençăo apenas à primeira parte do exame, considerando de modo específico os comandos para as produçôes escritas. Salientamos que entendemos como comando a questăo-estímulo oferecida ao candidato para que desenvolva sua produçâo escrita, compreendendo o enunciado da questăo e também textos e demais materiais de apoio para o desenvolvimento da proposta (FRANCO JÚNIOR; VASCONCELOS; MENEGASSI, 1997). Os comandos, desde o primeiro exame, já sinalizavam as condiçôes de produçăo e, ao longo dos anos, se aperfeiçoaram, buscando sinalizar de modo mais visível os elementos que possibilitam a escrita.

Nos três primeiros anos de aplicaçăo, o exame trazia, na parte escrita, uma produçáo textual e três atividades que envolviam a escrita, mas dentro de respostas interpretativas a questóes específicas sobre o texto, o vídeo ou o áudio dado. A partir da prova de 2000/1, passaram a ser quatro atividades de produçăo textual, cada uma enfocando um gênero discursivo diferente, mesmo que esse item nâo estivesse explícito em todos os comandos. Para mostrar a evoluçăo do exame, analisamos os comandos de três provas: 1998/1, 2006/1 e 2014/1. A escolha dessas ediçōes foi na tentativa de mostrar o início do processo (1998/1) e como está atualmente (2014/1), observando as alteraçóes e a concepçăo de proficiência subjacente ao processo ao longo dos dezesseis anos de existência do certificado. Para que a análise abrangesse todas as fases do exame, optamos por também trazer a versáo de 2006/1, que corresponde ao meio do processo, considerando o último exame aplicado.

Primeiramente, trazemos o único comando de produçăo escrita do exame de 1998/1:

\begin{abstract}
Tarefa IV
Após a leitura dos textos "Paulo Freire: A leitura de mundo", do jornal O Globo, de 3/5/97, e "Método usa dia a dia para alfabetizar", do jornal Folha de S. Paulo, de 3/5/97, imagine que você tenha decidido falar sobre Paulo Freire para alguns colegas que nunca ouviram falar sobre ele. Redija o texto que você vai apresentar a partir das informaçôes dos dois artigos que você leu, incluindo os seguintes argumentos:

dados sobre Paulo Freire;

características de sua proposta de alfabetizaçăo;

por que a proposta foi inovadora. (CELPE-BRAS 1998/1: Tarefa IV)
\end{abstract}

A primeira questăo a salientar sobre o comando é sua designaçăo, Tarefa, isso sinaliza para a produçăo textual, ou seja, é um trabalho que exige açôes efetivas do candidato, este năo deve assumir um papel passivo diante da proposta. Como diz Geraldi, a produçấo de texto ou de discurso faz com que o sujeito articule, no aqui e agora, um ponto de vista sobre o que se pede, "vinculado a uma certa formaçăo discursiva, dela nâo é decorrência mecânica, seu trabalho sendo mais da mera reproduçấo" (2003, p. 136). Essa característica permite que se obtenham, em conjunto com o restante do comando, novos discursos para cada candidato, impedindo que sejam sempre idênticos independente do autor.

Sobre as condiçōes de produçăo, observamos o seguinte:

- finalidade: apresentar Paulo Freire para colegas que nunca ouviram falar sobre ele;

- interlocutor: colegas que nunca ouviram falar sobre Paulo Freire; 
- gênero discursivo: năo definido;

- circulaçăo social: năo definido;

- suporte: embora tenhamos "falar sobre", indicando a voz como suporte, de fato, o texto năo circulará oralmente na situaçăo e prova, entăo podemos dizer que o suporte é a própria folha de redaçăo;

- posiçáo-autor: assume a si mesmo como autor.

Nessa tarefa, os principais elementos das condiçōes de produçăo foram oferecidos aos candidatos, finalidade e interlocutores, mas o gênero discursivo que deve ser definido a partir desses elementos iniciais năo está claramente exposto. Expóe-se, inicialmente, que o locutor decide "falar" sobre Paulo Freire, entâo poderíamos supor que se trata da produçấo de uma apresentaçấo oral. Logo em seguida, no entanto, temos "redija um texto"; a partir dessa informaçâo, entendemos que se trata de uma apresentaçăo escrita que seria, posteriormente, oralizada em situaçăo real de interaçăo. Essa ambiguidade gera ainda outra dúvida relativa à variedade da língua a ser selecionada, pois se sâo alguns amigos do locutor seus interlocutores, a variedade poderia ser informal. Por outro lado, se considerarmos que a apresentaçấo será escrita, a variedade a ser utilizada deve ser a formal.

Sobre o suporte textual, cabe refletir, aqui, um pouco mais, pois săo evidentes dois suportes: um real/concreto e outro virtual. O comando orienta que o texto será escrito com o fim de ser oralizado posteriormente, nesse caso, temos um suporte virtual, a voz, pois o ato de exposiçâo foi proposto no comando para dar condiçôes de o candidato adequar seu texto a esse suporte, mas a "fala" sobre o tema năo acontecerá efetivamente. O que o candidato terá ao final de sua escrita é o texto expresso na folha de redaçâo, por isso propomos que esta seja o suporte real da produçăo do candidato, a exemplo do que Bakhtin reflete sobre interlocutores reais e virtuais.

Afora essas questōes, observa-se que a primeira informaçấo é a posiçấo-autor, "imagine que você tenha decidido", dando margem para que o candidato exponha sua visăo sobre o assunto. Em seguida, tem-se o recorte temático "Falar sobre Paulo Freire" que se especifica melhor nas alíneas (dados sobre Paulo Freire; características de sua proposta de alfabetizaçấo; porque a proposta foi inovadora). Depois dessas informaçôes, sâo apresentados finalidade e interlocutores, o que define implicitamente a circulaçấo social e o suporte da produçấo, náo marcados no comando: circulará oralmente entre os amigos do locutor que desconhecem Paulo Freire.

O exame de 2006/1, cuja estrutura é a mesma desde 2001, fornece quatro tarefas de produçăo textual. O que se altera de uma para outra, além das condiçôes de produçăo, é o material de apoio: a primeira conta com a exibiçăo de um vídeo, a segunda com a audiçăo de um CD, a terceira e a quarta devem basear-se na leitura de uma reportagem. Salientamos que, aqui, optamos por apresentar a análise de um dos quatro comandos (Tarefas II) em funçâo do espaço que temos. O comando da Tarefa II, que deveria ser cumprida em vinte e cinco minutos, contando com a audiçăo do CD:

\section{FAMÍLIAS ACOLHEDORAS}

Você vai ouvir duas vezes uma entrevista da rádio Revista CBN (fevereiro de 2005) com Cláudia Cabral, diretora executiva de uma organizaçăo nâo-governamental (ONG), podendo fazer anotaçóes enquanto ouve. 
Convencido/a da importância do projeto, escreva uma carta aos moradores de seu bairro, estimulando o cadastramento de famílias acolhedoras. Sua carta deverá explicar o que é e como funciona o projeto e quais săo as motivaçōes das famílias que dele participam. (CELPE-BRAS 2006/1:Tarefa II, grifos do próprio exame)

Antes de abordar essa tarefa, cabe um esclarecimento sobre os grifos utilizados nos comandos do CELPE-BRAS. Ao fazer referência a jornais, revistas e outros meios de comunicaçấo conhecidos no Brasil, utiliza-se, nos primeiros formatos da prova, o itálico. A partir do exame 2005/2 até o de 2007/1, passou-se a ter o negrito, indicando as condiçôes de produçâo oferecidas aos candidatos. Analisamos, neste momento, o segundo, que contou com esse recurso.

Na Tarefa II, temos:

- finalidade: estimular o cadastramento de famílias acolhedoras;

- interlocutor: moradores do bairro do locutor;

- gênero discursivo: carta aberta;

- circulaçấo social: o bairro onde o locutor mora;

- suporte: náo definido;

- posiçăo-autor: é o próprio candidato a se posicionar em carta aberta.

A tarefa apresenta, em primeiro lugar, a posiçâo-autor, direcionando para que o candidato expresse a própria opiniâo sobre o recorte temático. Em seguida, sinalizamse o gênero discursivo, carta aberta, e os interlocutores, moradores do bairro do locutor, para, entâo, termos acesso à finalidade. Por fim, apresentam-se as informaçóes relativas ao tema que devem constar na produçăo textual. Ainda que năo haja a definiçăo do suporte, podemos supor que, sendo uma carta aberta, pode veicular em murais de estabelecimentos comerciais e públicos do bairro, bem como pode ser impressa e entregue na casa de cada um dos moradores da regiấo, em ambos os casos, poderiam ser veiculadas as mesmas informaçóes, nâo constituindo exatamente essa falha um prejuízo para o examinando.

A exemplo desse comando, os outros três do exame em questăo seguem a mesma postura, ou oferecendo todas as condiçóes de produçăo, ou deixando apenas uma de lado. Mesmo fazendo essas opçóes, nota-se que, como no caso da Tarefa II/2006/1, quando năo há definiçăo de algum dos elementos, ele está pressuposto, conforme demonstrado a respeito do suporte no parágrafo anterior. Nota-se ainda que todos os comandos desta ediçăo, diferente da de 1998/1, apresentam o gênero bem marcado. Além disso, temos a presença da posiçăo-autor, nos quatro comandos deste exame, como sendo o próprio candidato, explícito em expressóes como você, escreva, sua empresa, seu bairro. Quanto a essa questăo, notamos diferença em relaçăo ao último exame do CELPE-BRAS (2014/1).

A última ediçăo conta com estrutura idêntica à de 2006/1, sendo quatro tarefas voltadas para a produçấo textual. Citaremos em sequência as quatro tarefas de 2014/1 para, entăo, tecermos os comentários sobre cada uma delas. Seguem as Tarefas:

Tarefa 1 - CAFÉ (30 minutos, inclusa a exibiçăo do vídeo)

Você é publicitário e foi contratado para produzir o texto de apresentaçăo do cardápio de uma cafeteria. Com base nas informaçōes do vídeo, [(escreva um texto 
de apresentaçăo desse cardápio, inserindo curiosidades sobre o café e destacando as características de um café especial.)]

Tarefa 2 - CINEMATERNA (2h30min para fazer as tarefas 2, 3 e 4, inclusas nesse tempo escuta de áudio e leitura dos textos de apoio)

Você é colunista de uma revista voltada para măes de crianças pequenas. Com base nas informaçóes do áudio, escreva o texto (para ser pulicado na próxima ediçăo da revista), (explicando o que é Cinematerna, como ele surgiu, e encorajando as leitoras a participarem dessa iniciativa.]

\section{Tarefa 3 - BIBLIOTECA COMUNITÁRIA ILÊ ARÁ}

A Secretaria Municipal da Cultura de Porto Alegre está premiando açóes bemsucedidas na área social. Como chefe da Biblioteca Comunitária Ilê Ará, (você acredita que a iniciativa de levar livros a sua comunidade merece ser premiada.) Assim, escreva uma carta de apresentaçáo do trabalho realizado por vocês, no Morro da Cruz, direcionada à comissăo julgadora do prêmio. Em seu texto, [descreva a iniciativa e explique por que ela merece ser premiada.]

Tarefa 4 - GPS

Como colunista da seçăo "Última Palavra" da Revista Isto É, você decidiu escrever um texto colocando-se na posiçâo do taxista mencionado na crônica "GPS", de Zeca Baleiro. No texto, [narre a sua versăo dos fatos, posicionando-se em relaçăo ao uso da tecnologia na sociedade atual.] (CELPE-BRAS 2014/1 grifos nossos)

Legenda:

() - Finalidade

Sublinhado - posiçăo autor

Negrito - gênero discursivo

Itálico - suporte textual

[] - recorte temático

SalientadoInterlocutor

Nessa ediçăo năo há mais o uso de negrito para salientar as condiçôes de produçăo, nem do itálico para indicar meios de comunicaçâo conhecidos. Todos os comandos săo mais condensados e precisos, contendo a maioria dos elementos marcados no enunciado. Para facilitar a visualizaçăo nos comandos do que afirmamos na análise, grifamos os itens de formas diferenciadas, como indica a legenda.

Nota-se, pelos grifos, que a maioria dos elementos das condiçôes de produçâo pode ser encontrada em todos os comandos. O destaque vai para a posiçâo-autor que se diferencia dos demais comandos já analisados aqui - nos quais o candidato se posicionaria como ele mesmo -, pois há como uma construçăo de personagens, ou seja, ora o examinando deve se colocar como colunista, ora como chefe de uma biblioteca ou ainda como publicitário. Nesse caso, exige-se do candidato que ele saiba qual é a funçâo social desses profissionais para que se posicione como eles e possa ser eficiente na tarefa, demonstrando sua subjetividade a respeito do assunto a ser tratado a partir de tais imagens de autoria.

Estăo implícitas, nesse elemento em destaque, outras informaçóes como, por exemplo, o interlocutor (marcado apenas na Tarefa 3) e a circulaçáo social (esta náo 
marcado explicitamente em nenhum enunciado). Quanto ao interlocutor da tarefa 1, por exemplo, pode ser inferido pela posiçăo-autor publicitário contratado para fazer o texto de apresentaçáo do cardápio de uma cafeteria, pois embora náo esteja explícito no comando, serăo os clientes da cafeteria que terăo contato com o cardápio. Nesse caso, a circulaçấo social dessa produçăo fica restrita ao ambiente da cafeteria, informaçấo também pressuposta na posiçáo-autor. Nas tarefas 2 e 4, o candidato deve posicionarse enquanto colunista, no primeiro caso, de uma revista voltada para mâes de crianças pequenas, e, no segundo, da coluna Última Palavra da Revista IstoÉ. Seus interlocutores estăo marcados aqui, ou seja, na tarefa 2 , săo as máes de crianças pequenas e, na tarefa 4, leitores da Revista IstoÉ. A circulaçâo social dessas produçôes, entăo, restringe-se ao público específico de cada canal de comunicaçăo.

No que se refere ao gênero, mesmo náo estando marcado em todos os enunciados, já que na tarefa 2 e 4 temos a ordem para se escrever "um texto", pressupomos também pela posiçâo-autor que se trata de um artigo de opiniăo que ocupará a coluna das revistas. Na tarefa 1, pede-se um texto de apresentaçăo para um cardápio e, na 3, solicita-se uma carta de apresentaçấo. Em todos os comandos, há um direcionamento do gênero, o que facilita ao examinando selecionar estrutura composicional e estilo de escrita, bem como desenvolver o recorte temático de cada proposta. Cabe ressaltar aqui sobre esse recorte, todos os comandos têm um cuidado de deixar claros os itens temáticos que devem ser abordados pelo candidato, essa é uma constante da conduçăo do exame CELPE-BRAS em geral e nâo apenas dos analisados aqui.

A finalidade para a escrita desses gêneros está expressa nos três primeiros comandos, nos quais está marcada junto a outro elemento das condiçōes de produçâo. No primeiro comando, foi marcada junto ao gênero, "apresentar o cardápio". No segundo, foi marcada dentro do recorte temático, "explicar o que é cinematerna". Em seguida, na tarefa 3, novamente a finalidade aparece associada ao tema, "apresentar a biblioteca comunitária". Por fim, no último comando, junto à temática temos o intuito de dizer, "posicionar-se em relaçáo ao uso da tecnologia na sociedade atual". Observa-se que, como Bakhtin orienta, "o momento subjetivo [finalidade] - se combina em uma unidade indissociável com o seu aspecto semântico-objetivo [tema], restringindo este último, vinculando-o a uma situaçấo concreta (singular) de comunicaçăo discursiva" (2003, pp. 281-282), ou seja, a unidade que se apresenta entre tema e intuito de dizer promove a exposiçấo da subjetividade do candidato de acordo com o objetivo dado pelo comando, gerando uma finalidade real capaz de ordenar sua escrita.

O último elemento das condiçôes de produçâo a ser comentado é o suporte, que aparece combinado com outros elementos, vejamos os casos: na Tarefa 1, o texto deve ser produzido para ser publicado em um cardápio; na 2, o texto fará parte da próxima ediçăo da revista para máes de crianças pequenas; na 3, o próprio gênero configura o suporte, pois se trata de uma carta de apresentaçăo, portanto impressa; e, na última tarefa, o suporte é a Revista Isto É. A indicaçâo do suporte torna-se importante para definir extensáo da produçáo, a escolha lexical, a opção pela variedade linguística mais apropriada, etc. O suporte também permite, ao lado do conhecimento do interlocutor, medir o nível de informatividade do texto, uma vez que um texto que é publicado no cardápio, por exemplo, recebe menos atençăo do interlocutor do que o publicado em uma revista, pois o cliente está interessado em fazer suas escolhas para a refeiçáo, objetivo principal da consulta ao cardápio do que ler um texto midiático impresso. 
A partir da análise dos comandos apresentada aqui e das consideraçóes de todos os exames do CELPE-BRAS, pôde-se notar uma atençăo ao cumprimento das condiçóes de produçấo baseadas nos conceitos bakhtinianos. Ao longo dos anos, mostra-se a especializaçăo dos comandos, pois os dos primeiros exames traziam alguns itens nâo definidos, como mostramos no de 1998/1. Embora pudessem ser inferidos, havia menos possibilidades para isso, a exemplo da discussâo sobre o gênero para a escrita do comando dessa prova analisado aqui. Nota-se que, no exame de 2014/1, as inferências săo muito mais fundamentadas, pois estăo ancoradas nos elementos das condiçóes de produçâo apresentados. A evoluçấo também pode ser notada pelas tentativas de evidenciar tais elementos, como no uso do negrito para salientá-los durantes dois anos.

Outra indicativa da evoluçăo do exame e do ajuste aos conceitos bakhtinianos está na quantidade de produçōes textuais propostas. De 1998 a 2000, o candidato se deparava com apenas uma produçâo textual e, a partir de 2001, a escrita de textos passou a ocupar toda a prova. Isso demonstra a concepçăo de língua subjacente ao exame, língua como forma de interaçăo, pois em toda produçáo textual, propôe-se uma situaçăo de interaçâo social com todos os elementos necessários para que se configure como tal. Saber língua, nesse sentido, nâo é conhecê-la em sua estrutura, mas sim, saber o suficiente da estrutura para aplicá-la em situaçóes reais de interaçăo.

Com essa discussăo, podemos discutir outro de nossos objetivos que é compreender a concepçáo de proficiência escrita implícita no exame CELPE-BRAS. A primeira questăo a ser levada em conta é justamente a concepçăo de língua como forma de interaçăo nítida em todos os comandos para as produçôes escritas, endossando a ideia de que a interaçăo verbal é a realidade fundamental da língua. Ou seja, propóe-se nos comandos a produçâo de enunciados concretos (BAKHTIN/VOLOCHINOV, 2009) que exigem o domínio da língua adicional para uso em situaçōes interlocutivas, mas tal exigência náo está no nível da estrutura da língua adicional e sim o desenvolvimento de competências interacionais.

Nesse sentido, observando o cuidado do exame em apresentar situaçăo de interaçăo para que o texto do candidato faça sentido, observa-se que o foco náo está no primeiro conceito de proficiência apresentado por Scaramucci (2000), cuja preocupaçâo é o domínio de um conjunto de habilidades linguísticas estruturais. Está, sim, no conceito relativo e múltiplo citado por Uflacker (2012), que considera a especificidade da situaçâo de uso futuro da língua. Assim, ser proficiente na escrita é uma expressâo que, na perspectiva do CELPE-BRAS, vem sempre acompanhada de uma preposiçáo ser proficiente para indicando que há uma finalidade para se aprender português, isto é, para usá-lo em determinadas situaçōes interlocutivas.

Retomando Fortes (2009), temos no exame o que a autora chama de domínio de recursos interacionais para resolver as necessidades de interaçăo, bem como para suprir as dificuldades de compreensâo que possam haver entre os interlocutores. Desse modo, o essencial náo é concentrar a compreensăo na forma utilizada, é compreender a significaçâo dessa estrutura em uma enunciaçăo particular (BAKHTIN/VOLOCHINOV, 2009).

Para finalizar, temos, entâo, que o oferecimento dos elementos componentes das condiçôes de produçâo nos comandos de produçâo textual no CELPE-BRAS faz com que o candidato faça uso da língua portuguesa em situaçōes interlocutivas específicas semelhante àquelas com as quais ele vai se deparar no dia a dia em lugares em que se 
fale português. Está subjacente nessa conduçăo que proficiente em língua portuguesa como língua adicional é aquele que consegue aproveitar-se da estrutura linguística para usos reais. De nada adiantaria, partindo dessa ideia, ele saber formar frases em português, caso náo conseguisse fazer delas enunciados concretos que servem a um contexto determinado.

\section{CONSIDERAÇÕES FINAIS}

Este trabalho avaliou comandos do exame CELPE-BRAS, observando o modo como a sua conduçâo está engajada na produçâo de textos em situaçôes de interaçấo bem situadas. Pôde-se notar a evoluçăo dos exames ao longo dos anos, trazendo a cada época uma especializaçâo na apresentaçăo dos elementos que dâo conta das condiçôes de produçáo de enunciados concretos. Se no início das aplicaçōes, aos comandos faltavam elementos, com o passar do tempo, estes foram sendo integrados e apresentados com maior clareza. Mesmo nos momentos em que ficaram subentendidos, havia a possibilidade de apreensáo de tais itens a partir dos outros, conforme demonstrado.

A partir da análise dos comandos, verificou-se que há uma concepçâo de proficiência escrita em língua adicional que perpassa a construçăo dos exames. Segundo essa perspectiva, năo há como parâmetro de bom usuário da língua o falante nativo, é o indivíduo que é capaz de apropriar-se da estrutura linguística em prol de seus objetivos de interaçăo. Destaca-se que a interaçăo em língua adicional, em situaçôes reais, é construída com base nos elementos das condiçôes de produçáo, entăo nâo faz sentido cobrar do candidato que ele tenha conhecimentos isolados de estrutura que possivelmente nâo lhe ajudarâo no cotidiano, no uso real da língua. Parece que essa reflexâo guia a concepçâo de língua e de proficiência subjacentes à construçâo das provas do CELPE-BRAS.

Em dias como os atuais, em que se tem falado muito sobre língua adicional e especialmente no português como língua adicional, é importante pensar o que se quer da língua que se aprende. Em geral, o conhecimento interacional auxilia muito mais do que conhecer a estrutura por si só, um caso emblemático disso săo os usos transidiomáticos feitos em redes sociais, os indivíduos demonstram, em todo momento, que as línguas náo são monolíticas e năo se definem unicamente pela estrutura. Entăo, seria um retrocesso se os exames de proficiência fizessem perdurar uma visăo estruturalista de língua. Desse modo, discussóes como a que fazemos aqui contribuem no sentido de se pensar a língua, as línguas adicionais e como elas săo avaliadas. As discussōes aqui apresentadas também contribuem com o ensino de língua adicional e com os cursos preparatórios para o exame, pois mostram o enfoque da prova, sinalizando caminhos para a abordagem da produçăo textual. 


\section{REFERÊNCIAS}

BAKHTIN, M. Estética da criaçăo verbal. Săo Paulo: Martins Fontes, 2003. 1976.

VOLOCHINOV, N. Marxismo e filosofia da linguagem. 13. ed. Sáo Paulo: Hucitec,

; _. Discurso na vida e discurso na arte: sobre poética sociológica. Traduçăo: Carlos Alberto Faraco e Cristóvâo Tezza.In: VOLOSHINOV, N. Freudismo. Traduçăo: I. R. Titunik. New York: Academic Press, 1972. (Circulaçăo para uso didático).

FORTES, M. S. Uma compreensáo etnometodológica do trabalho de fazer ser membro na fala-em-interaçăo de entrevista de proficiência oral em português como língua adicional. 2009. 329f. Tese (Doutorado em Letras), Instituto de Letras, Universidade Federal do Rio Grande do Sul, Porto Alegre, 2009.

FRANCO JÚNIOR, A.; VASCONCELOS, S. I. C. C.; MENEGASSI, R. J. O vestibulando e o processo de escrever.In: BIANCHETTI, L. (Org.). Trama e texto: leitura crítica, escrita criativa. Sâo Paulo: Plexus,1997.v. 2, pp. 96-108.

FUZA, A. F.; MENEGASSI, R. J.A finalidade da escrita no livro didático: marcas no gênero discursivo. Uniletras, Ponta Grossa, v. 30, n.2, pp. 317-333, jul.-dez., 2008.

GERALDI, J. W. Portos de passagem. 4. ed. Săo Paulo: Martins Fontes, 2003.

(Org.). 0 texto na sala de aula. Săo Paulo: Ática, 1997.

INSTITUTO NACIONAL DE ESTUDOS E PESQUISAS EDUCACIONAIS ANÍSIO TEIXEIRA. 1998/1. CELPE-BRAS.

2006/1. CELPE-BRAS. 2006/1.

2014/1. CELPE-BRAS.

MENEGASSI, R. J. Conceitos bakhtnianos em comandos de prova de redaçáo.In: FIGUEIREDO, D. C. et al. (Orgs.). Sociedade, cogniçâo e linguagem: apresentaçôes do IX CELSUL. Florianópolis: INSULAR, 2012.

MOTERANI, N.; MENEGASSI, R. J. O conteúdo temático no gênero discursivo tiras em quadrinhos. Acta Scientiarum. Language and Culture. Maringá, v. 32, n. 2, pp. 225-232, 2010.

SCARAMUCCI, M. Proficiência em LE: consideraçôes terminológicas e conceituais. Trabalhos em Linguística Aplicada. Campinas, v. 36, pp. 11-22, julho-dezembro, 2000.

UFLACKER, C. M. Fazer avaliar na construçăo do participante competente. Porto Alegre:UFRGS, 2012. Tese. 223f.(Doutorado em Letras), Instituto de Letras, Universidade Federal do Rio Grande do Sul, Porto Alegre, 2012. 